\title{
PROFIL KOMUNIKASI MATEMATIKA SISWA DENGAN KECERDASAN LINGUISTIK DALAM MEMECAHKAN MASALAH DITINJAU DARI JENIS KELAMIN
}

\author{
Tria Winda Liana
}

\author{
Pendidikan Matematika, FMIPA, UNESA, email: trialiana@mhs.unesa.ac.id
}

Abdul Haris Rosyidi

Pendidikan Matematika, FMIPA, UNESA, email: abdulharis@unesa.ac.id

\begin{abstract}
Abstrak
Penelitian kualitatif ini bertujuan untuk mendeskripsikan komunikasi matematika siswa dalam memecahkan masalah. Indikator komunikasi matematika dalam pemecahan masalah mengacu pada langkah pemecahan masalah Polya dan Prayitno. Subjek penelitian ini adalah dua siswa yang memiliki kecerdasan linguistik tinggi. Instrumen penelitiannya adalah angket identifikasi kecerdasan linguistik, tes komunikasi matematika dan wawancara. Hasil penelitian menunjukkan bahwa siswa laki-laki mampu merumuskan informasi atau hal-hal yang diketahui dan ditanyakan secara tertulis dan lisan, mengungkapkan strategi penyelesaian dan memodelkan situasi dengan menggunakan simbol atau notasi matematika, menyatakan representasi matematika (rumus), menyelesaikan masalah sesuai langkah-langkah penyelesaian, serta menuliskan dan mengungkapkan kesimpulan. Sedangkan, untuk siswa perempuan perbedaannya pada kemampuan menggunakan simbol atau notasi matematika dalam menyelesaikan permasalahan.
\end{abstract}

Kata Kunci: komunikasi matematika, kecerdasan linguistik, pemecahan masalah.

\begin{abstract}
This qualitative research aims to describe students' mathematical communication in solving problems. Mathematical communication indicators in problem solving refer to Polya and Prayitno's problem solving steps. The subjects of this study were two students who had high linguistic intelligence. The research instrument was a linguistic intelligence indetification questionnaire, mathematics communication tests and interviews. The results show that male students are able to formulate information or things that are known and asked in witing and orally, express settlement strategies and model situations using mathematical symbols or notations, state mathematical representations (formulas), solve problems according to the steps completion, and write down and express conclusions. Meanwhile, for female students the difference is in the ability to use mathematical symbols or notations in solving problems.
\end{abstract}

Keywords: mathematics coomunication, linguistic intelligence, problem solving.

\section{PENDAHULUAN}

Dalam Peraturan Menteri Pendidikan dan Kebudayaan (Permendikbud) Nomor 21 Tahun 2016 tentang Standar Isi, disebutkan bahwa mata pelajaran matematika bertujuan agar siswa memiliki kemampuan mengkomunikasikan gagasan matematika dengan jelas. Senada dengan salah satu kompetensi dimensi keterampilan dalam pembelajaran matematika yaitu memiliki keterampilan komunikasi (Permendikbud, 2016). Komunikasi dapat diartikan sebagai proses penyampaian makna dalam bentuk gagasan atau informasi kepada seseorang melalui media tertentu (Hardjana, 2003). Dalam matematika menyampaikan atau menerima informasi tidaklah mudah karena matematika mengandung istilah dan simbol, sehingga kemampuan komunikasi matematika sangat diperlukan siswa, karena melalui komunikasi siswa dapat mengorganisasi dan mengkonsolidasi berpikir matematis serta mengeksplorasi ide-ide matematika (NCTM, 2000:128).
Berdasarkan uraian di atas, maka komunikasi matematika merupakan hal yang sangat penting dimiliki siswa. Oleh karena itu, siswa ditantang untuk memecahkan masalah matematika dan mampu mengomunikasikan pemikirannya, baik secara lisan maupun tertulis. Dalam hal ini, secara tidak langsung siswa dituntut untuk membangun ide-ide matematika menjadi lebih terstruktur, sehingga ide-ide matematika tersebut menjadi lebih mudah dipahami maknanya.

Berkenaan pentingnya pemecahan masalah, NCTM (2000:182), menyebutkan pemecahan masalah merupakan landasan matematika sekolah. Senada dengan NCTM, Cooney et. al. (dalam Ariawan, 2017:84) menyatakan bahwa mengajarkan siswa untuk memecahkan masalah memungkinkan siswa menjadi lebih analitis dalam mengambil keputusan di dalam kehidupan. Selanjutnya bila seorang siswa dilatih untuk memecahkan masalah, maka siswa itu akan mampu mengambil keputusan karena mempunyai keterampilan tentang bagaimana mengumpulkan informasi yang relevan, menganalisis 
informasi dan menyadari perlunya meneliti kembali hasil yang telah diperolehnya (Hudojo, 2003). Berdasarkan uraian di atas, maka kemampuan komunikasi matematika dan pemecahan masalah sangat penting dan menjadi fokus utama untuk dikembangkan, sehingga kemampuan komunikasi matematika yang dimiliki setiap siswa dapat digunakan untuk menginterpretasi dan mengekspresikan pemahamannya dalam memecahkan masalah.

Menurut pendapat Suriasumantri (2007), matematika merupakan bahasa yang melambangkan serangkaian makna dari pernyataan yang ingin disampaikan. Proses komunikasi dapat berlangsung melalui bahasa, dan kemampuan yang dimiliki seseorang akan memengaruhi penguasaan bahasa yang dimiliki. Lambang-lambang matematika bersifat artifisial yang baru mempunyai arti setelah sebuah makna diberikan padanya. Kecerdasan linguistik merupakan kemampuan seseorang dalam menggunakan bahasa atau kata-kata untuk mengomunikasikan gagasan atau ide secara lisan maupun tertulis. Sehingga dapat dikatakan bahwa tingkatan kecerdasan linguistik yang dimiliki siswa juga akan memengaruhi kemampuan siswa dalam mengomunikasikan makna dalam bahasa matematika. Berdasarkan hasil penelitian Ambarwati (2016) menunjukkan bahwa siswa dengan tingkat kecerdasan linguistik tinggi mampu mengungkapkan komunikasi matematika secara lisan dan tertulis dengan baik. Hal ini menunjukkan bahwa kecerdasan linguistik memegang peranan penting dalam kemampuan komunikasi matematika yang dimiliki siswa.

Faktor lain yang memengaruhi individu dalam mengomunikasikan ide-ide matematika, salah satunya adalah perbedaan jenis kelamin. Perbedaan jenis kelamin tidak hanya tentang masalah biologis saja, namun sekarang berkembang menjadi perbedaan kemampuan antara laki-laki dan perempuan. Banyak hasil penelitian terkini yang menyajikan adanya perbedaan prestasi belajar, sikap, dan partisipasi yang dipengaruhi perbedaan jenis kelamin (Goos, 2007). Para peneliti saat ini menyadari bahwa perbedaan hasil belajar matematika siswa yang dipengaruhi perbedaan jenis kelamin adalah tidak mutlak dan sering tertukar, hal ini juga dipengaruhi latar belakang sosial ekonominya. Secara umum perbedaan jenis kelamin dalam pretasi belajar matematika tergantung pada isi tugas, sifat pengetahuan dan keterampilan yang ditugaskan, serta kondisi saat mengerjakan tugas. (Goos, 2007). Oleh karena itu, dapat disimpulkan bahwa perbedaan jenis kelamin mempunyai andil untuk menerangkan profil seseorang dalam memecahkan masalah dan mengkomunikasikan hasilnya, namun perbedaan ini belum konsisten. Dengan demikian ketidakkonsistenan hasil dalam penelitian yang melibatkan kajian perbedaan jenis kelamin dalam suatu kelompok umur dan kelompok budaya yang berbeda tidak dapat dijelaskan hanya oleh jenis kelamin. Oleh karenanya, perbedaan jenis kelamin masih perlu diteliti lebih lanjut, termasuk dalam penelitian ini, yaitu terkait dengan kemampuan komunikasi matematika siswa dalam memecahkan masalah.

Beberapa penelitian telah menjelaskan bahwa komunikasi matematika siswa dalam pemecahan masalah dipengaruhi oleh jenis kelamin. Salah satunya penelitian Rohmah (2014), yang telah meneliti profil komunikasi matematika siswa dalam pemecahan masalah matematika ditinjau dari gaya kognitif dan jenis kelamin. Penelitian ini menyajikan perbedaan yang cukup signifikan tentang pengaruh gaya kognitif dan jenis kelamin terhadap komunikasi matematika siswa dalam memecahkan masalah matematika, dimana hasil penelitian ini menunjukkan subjek laki-laki dengan gaya kognitif FI (Field Independent) lebih unggul. Ada juga penelitian Kurniawati (2015), yang telah meneliti profil kemampuan komunikasi matematika siswa dalam pemecahan masalah matematika ditinjau dari perbedaan kemampuan matematika dan jenis kelamin. Penelitian ini menyajikan hasil yang berbeda, bahwa subjek perempuan dengan kemampuan matematika tinggi lebih unggul dalam memecahkan masalah matematika.

Penelitian ini bertujuan untuk mendeskripsikan komunikasi matematika siswa laki-laki dan perempuan dengan kecerdasan linguistik tinggi dalam memecahkan masalah.

\section{METODE}

Pendekatan yang digunakan dalam penelitian ini adalah pendekatan kualitatif. Pengumpulan data yang diperoleh dalam penelitian ini menggunakan instrumen (1) angket identifikasi kecerdasan linguistik, (2) tes komunikasi matematika tulis, dan (3) wawancara. Subjek penelitian ini adalah dua siswa SMP yang berkecerdasan tinggi. Penggolongan kecerdasan linguistik tinggi, sedang, dan rendah mengacu pada hasil angket identifikasi kecerdasan linguistik.

Tes Komunikasi Matematika Tertulis (TKMT) diberikan kepada subjek terpilih dilanjutkan wawancara. TKMT yang digunakan adalah sebagai berikut.

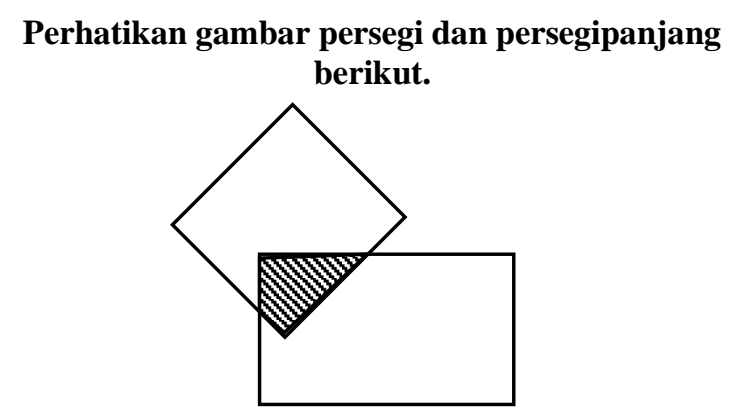

Gambar 1 Persegi dan Persegipanjang

Panjang sisi persegi $10 \mathrm{~cm}$. Panjang salah satu sisi persegipanjang adalah $12 \mathrm{~cm}$ dan panjang sisi yang lainnya adalah dua kali panjang sisi persegi. Berapa luas daerah irisan dua bangun tersebut jika luas daerah yang tidak diarsir adalah $180 \mathrm{~cm}^{2}$ ? Tuliskan secara lengkap langkah-langkah penyelesaiannya.

\section{HASIL DAN PEMBAHASAN}

Penggolongan kecerdasan linguistik tinggi, sedang, dan rendah menggunakan AIKL (Angket Identifikasi Kecerdasan Linguistik) berupa butir-butir pernyataan 
positif (favorable) sebanyak 20 poin. Setelah pengisian angket, dilakukan pen-skoran terhadap angket identifikasi kecerdasan linguistik yang dikerjakan oleh siswa. Berdasarkan hasil angket identifikasi kecerdasan linguistik, diperoleh data seperti yang disajikan pada Tabel 1 berikut ini.

Tabel 1 Data Hasil Angket Identifikasi Kecerdasan Linguistik

\begin{tabular}{|c|c|c|c|c|c|c|c|c|c|}
\hline \multicolumn{5}{|c|}{ Linguistik } & \multirow[t]{2}{*}{ No. } & \multirow{2}{*}{$\begin{array}{l}\text { Nama } \\
\text { Siswa }\end{array}$} & \multirow{2}{*}{ Subjek } & \multirow{2}{*}{ Kelamin } & Kecerdasan \\
\hline \multirow{3}{*}{ No. } & Inisial & & Skor & Tingkatan & & & & & Linguistik \\
\hline & Nama & Jenis Kelamin & AIKL & Kecerdasan & 1. & $\mathrm{ADB}$ & $\mathrm{LT}$ & Laki-Laki & Tinggi \\
\hline & Siswa & & (skala 60) & Linguistik & 2. & NMD & PT & Perempuan & Tinggi \\
\hline
\end{tabular}

\section{Komunikasi Matematika LT}

Hasil Tes Komunikasi Matematika LT tertulis pada Gambar 2 berikut.

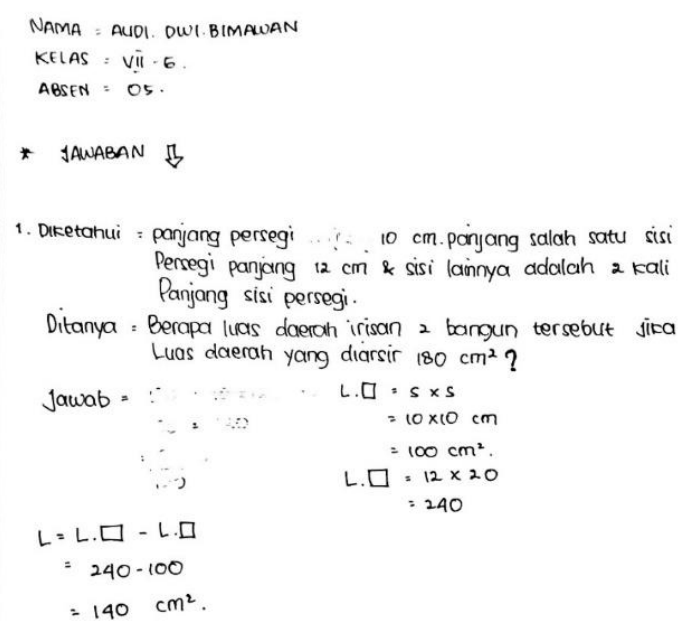

Gambar 2 Hasil Tes Komunikasi Matematika LT

Berikut ini petikan wawancara dengan LT terkait komunikasi matematika dalam pemecahan masalah pada langkah memahami masalah.

\section{1) Memahami Masalah}

LT01P : Apakah kamu sudah memahami permasalahannya?

LT01S : Sudah.

LT02P : Oke, coba jelaskan informasi apa saja yang kamu dapatkan dari permasalahan tersebut?

LT02S : Diketahui panjang sisi persegi adalah $10 \mathrm{~cm}$, panjang persegipanjang adalah $20 \mathrm{~cm}$ dan lebar persegipanjang adalah $12 \mathrm{~cm}$, serta luas daerah yang tidak diarsir adalah $180 \mathrm{~cm}^{2}$ dan yang ditanyakan adalah luas daerah yang diarsir.

LT03P : Dari informasi yang kamu jelaskan, apakah kamu juga memahami simbolsimbol atau notasi dari permasalahan tersebut? 
LT03S : Di dalam permasalahan tersebut, saya tidak menemui simbol, sehingga saya memisalkan beberapa simbol sendiri. Seperti simbol luas persegi, saya simbolkan dengan L $\square$ dan persegipanjang dengan $\amalg \square$. Lalu simbol untuk sisi persegi dengan s, serta simbol luas seluruhnya dengan L, tidak lupa dengan mencantumkan simbol satuan sisi dan luas.

Siswa dapat merumuskan informasi yang diketahui dan ditanyakan secara tertulis (Gambar 2) dan menyebutkan hal-hal yang diketahui dalam permasalahan seperti panjang dan lebar sisi persegi dan persegipanjang (LT02S), serta siswa dapat memisalkan simbol atau notasi matematika dengan mengacu pada permasalahan (LT03S).

2) Merencanakan Penyelesaian Masalah

LT04P : Bagaimana strategimu untuk menyelesaikan permasalahan tersebut?

LT04S : Pertama, saya akan menentukan luas persegi terlebih dahulu, kemudian menentukan luas persegipanjang. Setelah itu menentukan selisih antara luas persegi dan persegipanjang.

Siswa dapat mengungkapkan strategi berupa langkah-langkah penyelesaian dan memodelkan situasi dengan menggunakan simbol atau notasi matematika (LT04S).

3) Melaksanakan Rencana Penyelesaian Masalah

LT05P : Coba kamu tuliskan strategimu dengan menjelaskan satu persatu langkahlangkahnya.

LT05S : Pertama, menentukan luas persegi

$\mathrm{L} \boldsymbol{\mathbf { a }}=10 \mathrm{~cm} \times 10 \mathrm{~cm}$

$\mathrm{L} \boldsymbol{\nabla}=100 \mathrm{~cm}^{2}$

Lalu menentukan luas persegipanjang

$L \mathbf{\square}=12 \mathrm{~cm} \times 20 \mathrm{~cm}$

$L \square=240 \mathrm{~cm}^{2}$

Kemudian menentukan selisih antara luas persegi dan persegipanjang

$$
\begin{aligned}
& L=L \mathbf{\square}-L \mathbf{\square} \\
& L=240 \mathrm{~cm}^{2}-100 \mathrm{~cm}^{2} \\
& L=140 \mathrm{~cm}^{2}
\end{aligned}
$$

Siswa dapat menuliskan (Gambar 2) dan menyatakan representasi matematika atau rumus (LT05S), menyelesaikan masalah sesuai langkahlangkah penyelesaian dengan menggunakan simbol atau notasi dan operasi matematika (Gambar 2).

\section{4) Melakukan Pengecekan Kembali}

LT06P : Coba kamu cek kembali hasil pekerjaanmu, kesimpulan yang bisa kamu buat?

LT06S : Jadi, luas daerah yang diarsir adalah $140 \mathrm{~cm}^{2}$
Siswa dapat menuliskan (Gambar 2) dan mengungkapkan kesimpulan atas permasalahan yang diberikan (LT06S).

\section{Komunikasi Matematika PT}

Hasil Tes Komunikasi Matematika PT tertulis pada Gambar 3 berikut.

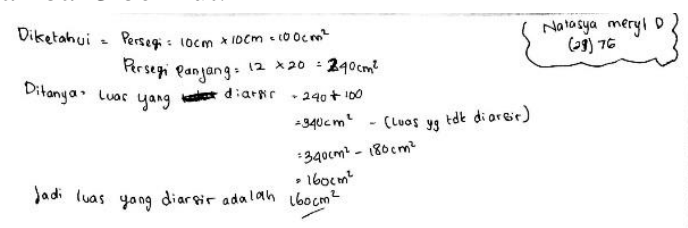

Gambar 3 Hasil Tes Komunikasi Matematika PT

Berikut ini analisis indikator komunikasi matematika pada setiap langkah pemecahan masalah Polya dengan menggunakan wawancara terhadap subjek PT berdasarkan hasil tes.

1) Memahami Masalah

PT01P :Apakah kamu sudah memahami permasalahannya?

PT01S : Sudah.

PT02P : Oke, coba jelaskan informasi apa saja yang kamu dapatkan dari permasalahan tersebut?

PT02S : Diketahui panjang sisi persegi adalah $10 \mathrm{~cm}$, jadi luas persegi $100 \mathrm{~cm}^{2}$. Panjang persegipanjang adalah $20 \mathrm{~cm}$ dan lebar persegipanjang adalah 12 $\mathrm{cm}$, jadi luas persegipanjang $240 \mathrm{~cm}^{2}$, dan yang ditanyakan adalah luas daerah yang diarsir.

PT03P : Dari informasi yang kamu jelaskan, apakah kamu juga memahami simbolsimbol atau notasi dari permasalahan tersebut?

PT03S : Di dalam permasalahan tersebut, saya tidak menemui simbol.

Siswa mampu merumuskan informasi yang diketahui dan ditanyakan secara tertulis (Gambar 3) dan mampu menyebutkan hal-hal yang diketahui dalam permasalahan (PT02S), namun siswa tidak menggunakan simbol atau notasi matematika (PT03S).

2) Merencanakan Penyelesaian Masalah

PT04P : Bagaimana strategimu untuk menyelesaikan permasalahan tersebut?

PT04S : Pertama, saya akan menentukan luas persegi terlebih dahulu, kemudian menentukan luas persegipanjang. Setelah itu menentukan jumlah antara luas persegi dan persegipanjang. Lalu mengurangkan dengan luas daerah yang tidak diarsir.

Siswa dapat mengungkapkan strategi berupa langkah-langkah penyelesaian (PT04S). Siswa tidak dapat memodelkan situasi dengan 
menggunakan simbol atau notasi matematika (Gambar 3).

3) Melaksanaka Masalah

PT05P : Coba kamu tuliskan strategimu dengan menjelaskan satu persatu langkahlangkahnya.

PT05S : Pertama, menentukan luas persegi

$L \boldsymbol{\square}=10 \mathrm{~cm} \times 10 \mathrm{~cm}$

$$
=100 \mathrm{~cm}^{2}
$$

Lalu menentukan luas persegipanjang

$$
\begin{aligned}
L \boldsymbol{\square} & =12 \mathrm{~cm} \times 20 \mathrm{~cm} \\
& =240 \mathrm{~cm}^{2}
\end{aligned}
$$

Kemudian menentukan jumlah antara luas persegi dan luas persegipanjang, lalu mengurangkan dengan luas yang tidak diarsir.

$L=(L \mathbf{\square}+L \mathbf{\square})-$ luas yg tidak diarsir

$$
\begin{aligned}
& =340 \mathrm{~cm}^{2}-180 \mathrm{~cm}^{2} \\
& =160 \mathrm{~cm}^{2}
\end{aligned}
$$

Siswa dapat mengungkapkan representasi matematika, menyelesaikan masalah sesuai langkah-langkah penyelesaian (PT05S). Siswa tidak menggunakan simbol/notasi dan operasi matematika secara tertulis (Gambar 3).

4) Melakukan Pengecekan Kembali

PT06P : Coba kamu cek kembali hasil pekerjaanmu, kesimpulan yang bisa kamu buat?

PT06S : Jadi, luas daerah yang diarsir adalah $160 \mathrm{~cm}^{2}$

Siswa dapat menuliskan dan mengungkapkan kesimpulan atas permasalahan yang diberikan

\begin{tabular}{|c|c|c|}
\hline $\begin{array}{l}\text { Kemampuan Komunikasi } \\
\text { Matematika pada langkah }\end{array}$ & $\begin{array}{l}\text { Subjek Laki-laki dengan } \\
\text { kecerdasan linguistik tinggi }\end{array}$ & $\begin{array}{l}\text { Subjek Perempuan dengan } \\
\text { kecerdasan linguistik tinggi }\end{array}$ \\
\hline 1. Memahami Masalah & $\begin{array}{l}\text { Siswa mampu merumuskan informasi } \\
\text { atau hal-hal yang diketahui dan } \\
\text { ditanyakan secara tertulis dan lisan, } \\
\text { serta dapat menggunakan simbol atau } \\
\text { notasi matematika. }\end{array}$ & $\begin{array}{l}\text { Siswa mampu merumuskan informasi } \\
\text { yang diketahui dan ditanyakan secara } \\
\text { tertulis dan lisan, siswa tidak dapat } \\
\text { menggunakan simbol atau notasi } \\
\text { matematika. }\end{array}$ \\
\hline $\begin{array}{l}\text { 2. Merencanakan Penyelesaian } \\
\text { Masalah }\end{array}$ & $\begin{array}{l}\text { Siswa dapat menuliskan dan } \\
\text { mengungkapkan strategi berupa } \\
\text { langkah-langkah penyelesaian dan } \\
\text { memodelkan situasi dengan } \\
\text { menggunakan simbol atau notasi } \\
\text { matematika. }\end{array}$ & $\begin{array}{l}\text { Siswa dapat mengungkapkan strategi } \\
\text { berupa langkah-langkah penyelesaian. } \\
\text { Siswa tidak dapat memodelkan situasi } \\
\text { dengan menggunakan simbol atau } \\
\text { notasi matematika. }\end{array}$ \\
\hline $\begin{array}{l}\text { 3. Melaksanakan Rencana } \\
\text { Penyelesaian Masalah }\end{array}$ & $\begin{array}{l}\text { Siswa dapat menyatakan representasi } \\
\text { matematika (rumus), menyelesaikan } \\
\text { masalah sesuai langkah-langkah } \\
\text { penyelesaian dengan menggunakan } \\
\text { simbol atau notasi dan operasi } \\
\text { matematika. }\end{array}$ & $\begin{array}{l}\text { Siswa dapat mengungkapkan } \\
\text { representasi matematika (rumus), } \\
\text { menyelesaikan masalah sesuai langkah- } \\
\text { langkah penyelesaian. Siswa tidak } \\
\text { dapat menggunakan simbol atau notasi } \\
\text { dan operasi matematika secara tertulis. }\end{array}$ \\
\hline 4. Melakukan Pengecekan Kembali & $\begin{array}{l}\text { Siswa dapat menuliskan dan } \\
\text { mengungkapkan kesimpulan atas } \\
\text { permasalahan yang diberikan. }\end{array}$ & $\begin{array}{l}\text { Siswa dapat menuliskan dan } \\
\text { mengungkapkan kesimpulan atas } \\
\text { permasalahan yang diberikan. }\end{array}$ \\
\hline
\end{tabular}
(PT06S).

Berdasarkan hasil komunikasi matematika dari LT dan PT di atas, diperoleh data seperti pada Tabel 3.

Tabel 3 Pembahasan Hasil Komunikasi Matematika

Berdasarkan Tabel 3, dapat diketahui bahwa siswa laki-laki dan perempuan berkecerdasan linguistik tinggi dapat mengungkapkan secara tertulis dan lisan mengenai informasi yang diperoleh dalam permasalahan, serta dapat mengungkapkan strategi penyelesaian masalah secara tertulis dan lisan. Perbedaannya terletak pada kemampuan menuliskan simbol atau notasi matematika, siswa laki-laki dapat menuliskan simbol atau notasi matematika secara tertulis dan lisan, sedangkan siswa perempuan tidak dapat menuliskan simbol atau notasi matematika secara tertulis.

Penelitian sebelumnya Rohmah (2014), yang telah meneliti profil komunikasi matematika siswa dalam pemecahan masalah matematika ditinjau dari gaya kognitif dan jenis kelamin. Penelitian ini menyajikan perbedaan yang cukup signifikan tentang pengaruh gaya kognitif dan jenis kelamin terhadap komunikasi matematika siswa dalam memecahkan masalah matematika, dimana hasil penelitian ini menunjukkan subjek laki-laki dengan gaya kognitif FI (Field Independent) lebih unggul. Ada juga penelitian Kurniawati (2015), yang telah meneliti profil kemampuan komunikasi matematika siswa dalam pemecahan masalah matematika ditinjau dari perbedaan kemampuan matematika dan jenis kelamin. Penelitian ini menyajikan hasil yang berbeda, bahwa subjek perempuan dengan kemampuan matematika tinggi lebih unggul dalam memecahkan masalah matematika. Sedangkan, hasil penelitian ini menunjukkan profil komunikasi matematika siswa laki-laki berkecerdasan linguistik tinggi dalam pemecahan masalah lebih unggul secara tertulis dan lisan daripada siswa perempuan berkecerdasan linguistik tinggi.

\section{PENUTUP \\ Kesimpulan}

Dari hasil penelitian yang telah dilaksanakan, dapat disimpulkan bahwa dalam tahap memahami masalah, siswa laki-laki mampu merumuskan informasi atau hal-hal yang diketahui dan ditanyakan secara tertulis dan lisan, serta dapat menggunakan simbol atau notasi matematika. Sedangkan, siswa perempuan juga mampu merumuskan informasi atau hal-hal yang diketahui dan ditanyakan secara tertulis dan lisan, tetapi tidak mampu menggunakan simbol atau notasi matematika. Berdasarkan indikator komunikasi matematika dalam pemecahan masalah Polya dan Prayitno, pada tahap merencanakan penyelesaian masalah, siswa laki-laki mampu menuliskan dan mengungkapkan strategi berupa langkah-langkah penyelesaian dan memodelkan situasi dengan menggunakan simbol atau notasi matematika. Sedangkan, siswa perempuan juga dapat mengungkapkan strategi berupa langkah-langkah penyelesaian, tetapi tidak dapat memodelkan situasi dengan menggunakan simbol atau notasi matematika.

Selanjutnya pada tahap melaksanakan rencana penyelesaian masalah, siswa laki-laki dapat menyatakan representasi matematika (rumus), menyelesaikan masalah sesuai langkah-langkah penyelesaian dengan menggunakan simbol atau notasi dan operasi matematika. Sedangkan, siswa perempuan juga dapat mengungkapkan representasi matematika (rumus), menyelesaikan masalah sesuai langkah-langkah penyelesaian, tetapi tidak dapat menggunakan simbol atau notasi dan operasi matematika secara tertulis. Selanjutnya tahap terakhir yaitu melakukan pengecekan kembali, kedua siswa laki-laki dan perempuan 
dapat menuliskan dan mengungkapkan kesimpulan atas permasalahan yang diberikan.

\section{Saran}

Berdasarkan hasil dari penelitian, ada beberapa saran yang diajukan oleh peneliti, sebagai berikut

1. Dalam penelitian ini terdapat perbedaan kemampuan komunikasi matematika siswa lakilaki dan siswa perempuan dalam memecahkan masalah, terutama pada siswa perempuan yang tidak dapat memodelkan situasi dengan menggunakan simbol atau notasi matematika. Oleh karena itu sebaiknya guru harus lebih memperhatikan komunikasi matematika baik tertulis maupun lisan dari masing-masing siswa.

2. Guru harus lebih teliti dalam pembelajaran terutama untuk mengetahui kemampuan komunikasi matematika dari masing-masing siswa.

\section{DAFTAR PUSTAKA}

Ariawan, Rezi. 2017. "Hubungan Kemampuan Pemecahan Masalah Matematis dengan Kemampuan Komunikasi Matematis Siswa". E-Journal THEOREMS (The Original Research of Mathematics). Vol.1 No.2, hal 8291.

Depdiknas, (2004). Permendiknas No.24 tahun 2004. Jakarta: Depdiknas.

Depdiknas. (2008). Kamus Besar Bahasa Indonesia. Jakarta: Pusat Bahasa.

Gardner, H. (2003). Multiple Intelligences: Kecerdasan Majemuk Teori Dalam Praktek. Batam Centre: Interaksara

Goos, M, Stillman, G \& Vale, C. 2007. Teaching Secondary School Mathematics, Research and Practice for the 21st Century. Crows Nest: Allen \& Unwin

Greenes, C., dan Schulman, L. 1996. Communication Processes in Mathematical Explorations and Investigations. In. P. C. Elliott and M. J. Kenney (Eds). Communication in Mathematics K-12 and Beyond. USA: NCTM.
Hudojo, Herman. 2001. Pengembangan Kurikulum dan Pembelajaran Matematika. UNM.

Kemendikbud. 2016. Lampiran Permendikbud Nomor 21 Tentang Standar Isi. Jakarta: Kementerian Pendidikan Kebudayaan.

Kurniawati, Ludvia Tri. 2015. Profil Kemampuan Komunikasi Matematika Siswa dalam Pemecahan Masalah Matematika Ditinjau dari Perbedaan Kemampuan Matematika dan Jenis Kelamin. Skripsi tidak dipublikasikan. Surabaya: Universitas Negeri Surabaya.

Miles, Matthew B. dan Huberman, A. Michael. 1992. Analisis Data Kualitatif (Alih Bahasa: Tjetjep Rohendi Rohidi). Jakarta: UI Press.

Moleong, Lexy J. 2005. Metodologi Penelitian Kualitatif. Bandung: Remaja Rosdakarya.

NCTM. 2000. Curriculum and Evaluation Standard for School Mathematics. Reston, VA: NCTM

Polya, George. 1973. How to Solve It. New Jersey: Princeton University Press.

Prayitno, Sudi. 2013. “Identifikasi Indikator Kemampuan Komunikasi Matematika Siswa dalam Menyelesaikan Soal Matematika Berjenjang pada Tiap-Tiap Jenjangnya". KNPM V, Himpunan Matematika Indonesia.

Rahmawati, Karina. 2016. "Faktor-Faktor yang Mempengaruhi Kecerdasan Linguistik". EJournal Pendidikan Guru Sekolah Dasar. Edisi 3 Tahun ke-5, hal 229.

Rohmah, Nailatur. 2014. Profil Komunikasi Matematika Siswa dalam Pemecahan Masalah Matematika Ditinjau dari Gaya Kognitif dan Jenis Kelamin . Skripsi tidak dipublikasikan. Surabaya: Universitas Negeri Surabaya.

Sugiarto, Hendik. 2014. "Kemampuan Komunikasi Matematika Siswa SMP dalam Pemecahan Masalah Ditinjau dari Kemampuan Matematika". E-Journal Ilmiah Pendidikan Matematika. Volume 3 No. 3. 